\title{
Customer Satisfaction Index for Transport Services
}

Submitted $22 / 02 / 18,1^{\text {st }}$ revision $8 / 05 / 19,2^{\text {nd }}$ revision $25 / 09 / 19,3^{\text {rd }}$ revision $15 / 2 / 19$, accepted 5/3/19

\author{
Adi Nurmahdi ${ }^{1}$
}

\begin{abstract}
:
Marketing activities through e-marketing and mobile marketing technology operated by online taxi players, such as, Grab and Uber have an impact on the transportation sector, especially operators which serve the Greater Jakarta / Jabodetabek (Jakarta, Bogor, Depok, Tangerang and Bekasi) area to and from Soekarno Hatta International Airport (SHIA).

Operators were worried that the advancement of online taxis could ruin their market share. Thus, customer insight information is needed. Exploratory research which measures customers' perception and focuses on Product Quality and ServQual was applied in this research. Non-probability, purposive sampling was used, with 134 loyal bus customers were chosen.
\end{abstract}

These matched the criteria of having travelled the specified route at least five times within the last 12 months. Importance Performance Analysis (IPA), which measures the relationship between customer perception and priority on increasing product or service quality, was applied. IPA combines the measurements of importance (degree of care) and performance (degree of satisfaction) in two dimensions which would make it easier to explain and describe practical suggestions.

Customer Satisfaction Index (CSI) was applied and scored 75.05 which means that customers were satisfied. This was derived from the overall weighted score of five ServQual dimensions: tangibles, assurance, reliability, responsiveness, and empathy.

This study concluded that even though the CSI result was satisfactory, to defend and enhance the market share, new innovative marketing strategies were needed, including the introduction of new technology in marketing and operations, in order to increase the overall quality of services to customers.

Keywords: Service quality, customer satisfaction index, airport bus transportation.

\footnotetext{
${ }^{I}$ Faculty of Economics and Business, Universitas Mercubuana, Jakarta, Indonesia email: adi.nurmahdi@mercubuana.ac.id
} 


\section{Introduction}

Improper implementation of marketing policies has become detrimental to the success of many companies. Customer oriented philosophy, which could enhance closeness to customers, is needed to enhance demands from the targeted market segments for operators serving SHIA - Jabodetabek routes. Effectiveness in implementing marketing policies matters, thus policies should be frequently updated following the market dynamics and controlled tightly, and firms should be aware of the parameters that could measure the results of marketing implementation. The objectives of this research were to analyze insight from customers which focuses on the customer satisfaction index and to measure the degree of importance and performance analysis based on two variables: quality of service, and Service Quality (ServQual) with its five dimensions: tangibles, assurance, reliability, responsiveness, and empathy applied. Gap analyses activities were applied. The object of the research were the individual customers of operators at SHIA airport - Jabodetabek routes.

The scope of this research focused on the effectiveness of marketing policies implementation of the operators obtained by interviewing customers who have travelled at least five times within the last 12 months using one of the five operators serving the routes. The operators included: Perum Damri, Hiba Utama, Agra Mas, Sinar Jaya, and X-Trans. Thus, this research represents a snapshot of the operators as perceived by their customers, and the period of research was from January to June 2017.

\section{Literature review}

\subsection{Product quality}

According to Juran (1998) it is not easy to define the word Quality since it is perceived differently by different individuals. If experts are asked to define quality, they may give varied responses depending on their individual preferences. These may be similar to the following listed phrases. The word quality can be defined either as fitness for use or purpose. To do the right thing at the first time, to do a right thing at the right-time, to find out what consumer wants. Features that meet consumer needs and give customer satisfaction, freedom from deficiencies or defects, conformance to standards, value or worthiness for money. As for the operators serving the routes, product quality matters a lot as it can be used as one of the competitive tools in the market.

\subsection{Service quality (ServQual)}

Operators might want to know what customers (internal or external) care about. Service quality is one of the prominent items, however the degree of product quality also counts. But for service providers, customers care most about service quality. 
Parasuraman, Zeithaml, and Berry (1995) found five dimensions customers use when evaluating service quality. They named their survey instrument ServQual. In other words, if the bus providers get these dimensions right, customers will become loyal and they will have received service excellence. The ServQual items include:

a) Tangibles: the appearance of physical facilities, equipment, personnel, and communication materials.

b) Reliability: the ability to perform the promised service dependably and accurately.

c) Responsiveness: willingness to help customers and provide prompt service.

d) Assurance: knowledge and courtesy of employees and their ability to convey trust and confidence.

e) Empathy: caring, individualized attention the firm provides its customers.

\subsection{Importance performance analysis}

Martilla and James (1997) described importance-performance analysis, a method used to determine the effectiveness and consumer acceptance of marketing programs. According to them, marketers must first identify the key features of their marketing mix, using methods such as personal interviews, focus groups and managerial judgment. They noted that importance measures and performance should be kept separate from one another. They also emphasized the ability to bring the marketer's attention to aspects of a marketing program that need improvement.

\subsection{Customer Satisfaction Index (CSI)}

Adapted from the American Customer Satisfaction Index (ACSI), CSI is a measure of how products and services supplied by a company meet or surpass customer expectations. They focus employees on the importance of fulfilling customers' expectations. Customer satisfaction scores and customer satisfaction indices are an attempt to measure how satisfied customers are with the performance of the company. The assumption being that the more satisfied a customer is, the more likely they are to stay as a customer. A customer satisfaction index combines the customer survey scores from different business attributes to create a single customer satisfaction index that indicates the overall customer satisfaction. The main issue with this approach is determining how important each attribute is in driving customer satisfaction. In this research, CSI Index was observed to analyze customers' perception towards the quality of services provided by the operators during the transactions.

\section{Methodology}

The Methodology used for this research included qualitative and quantitative research, including data obtained from desk research and surveys during the period between January and June 2017. It was a one shot, cross-sectional study, using a 
non-probability sampling technique. 134 samples were selected based on the subjective judgments of the researcher, with purposive sampling criteria i.e. customers who have travelled at least five times within the last twelve months using one of the operators. SPSS version 22.0 was used for analysis and secondary data was derived from textbooks, journals and websites.

\section{Findings and argument}

\subsection{Market environment}

The main target segment of the operators were individuals and families, middle to upper middle-income classes, frequent travellers, as well as, workers at SHIA area looking for cheap affordable fares. The growth in demand during the period of 20092016 was of around 24\%, and daily sales of around 30.000 seats. Since 2014, the Ministry of Transportation allowed operators, apart from Perum Damri, to serve the SHIA - Jabodetabek route. Apart from the existing players - Perum Damri, Hiba Utama, Agra Mas, Sinar Jaya and X-Trans - there are other indirect competitors, including online taxi operators, such as, Grab and Uber.

This year the SHIA railway link connects the city centre to commence. The range of fares varies from Rp. 40.000,- to Rp. 75.000,- one way. Another issue has been the increased number of the middle-income class and the ability of purchasing cars though credit. Environment conditions, such as smoke and forest fire, also determine demand. Since 2014, the Ministry of Transportation changed its policy of floor pricing for low-cost carriers, thus, fares for airlines nowadays are not as cheap as before the policy was introduced.

\subsection{Perceived marketing performance - customer satisfaction}

Respondents' Profile: $61 \%$ of the respondents surveyed were male with ages ranging from 17 years to senior citizens of 65 years, and $38 \%$ of them live in the Jabodetabek areas and the rest come from other cities.

\subsubsection{Gap Analysis}

The Gap analysis for dimension Product Quality and ServQual: Tangibles, Assurance, Reliability, Responsiveness, and Empathy, obtained the following results:

a) On average, the total average performance of operators was -0.39 , below customers' expectations.

b) The highest negative gaps obtained were for the dimension Responsiveness, with -0.64 , then for Empathy and Tangibles each with a score of -0.32 and -0.30 respectively. 
Table 1. Gap Analysis Product Quality and ServQual

\begin{tabular}{llll}
\hline Dimension & Performance & Importance & $\begin{array}{l}\text { Gap (Performance - } \\
\text { Importance) }\end{array}$ \\
\hline Product Quality & 3.78 & 3.60 & 0.18 \\
Tangibles & 3.94 & 4.24 & -0.30 \\
Reliability & 3.63 & 4.77 & -1.14 \\
Responsiveness & 3.77 & 4.41 & -0.64 \\
Empathy & 3.86 & 4.18 & -0.33 \\
Assurance & 4.15 & 4.28 & -0.13 \\
Average & 3.85 & 4.25 & -0.39 \\
\hline
\end{tabular}

Source: Researcher, 2017.

As for Product Quality indicators, product quality does matters for customers. Its performance revealed that there were gaps, with the Degree of Advancement in Operation with a gap -0.86 , followed by Promotion Informative and Routes Vary with gaps -0.74 and -070 respectively, thus operators need to focus to rectify the situation.

\subsubsection{Degree of importance}

For the degree of importance, out of the total score of 100 with five selected attributes, the customers decided:

a) Knowledge of the crew was the most important point for the customers with a score of 22.34 .

b) Physical appearance, equipment, crew, communication materials being the second most important with a score of 21.77 .

c) The ability for the operators to provide services as promised with a score of 20.36

d) Individual attention to customers with a score of 18.45 .

e) Availability of the crew to help customers in serving them in the best possible way with a score of 17.09 .

\subsubsection{Degree of customer loyalty}

The measurement of degree of customer loyalty with the scale of $7(100 \%)$ obtained the following results:

a) Refer others having the highest score with $83.24 \%$.

b) Friendliness with a score of $80.11 \%$.

c) Customer orientation with a score of $79.57 \%$.

This result revealed that the customers tend to be loyal to the operators and they would refer others for purchasing. Other positive results included friendliness and customer orientation provided by the operators. 


\subsubsection{Importance Performance Analysis (IPA)}

Figure 1 below revealed overall IPA results as follows:

a) Quadrant 1 Concentrate here means actions needed to be focused by the operators towards three items - Reliability, Responsiveness and Empathy. Thus the skills of the crews needed to be upgraded.

b) Tangibles and Assurance were in Quadrant 2 Keep up the good work which reflected the physical evidence and assurance for safety have provided satisfactory performance and must be kept up.

c) Product quality in Quadrant 3 - low priority - which means it was not the main focus for customers, they felt that it was sufficient, though maintaining and upgrading product and services are still important tasks for the operators.

d) No item was located at Quadrant 4 - Possibly Overkill - which means strategies implementation of the operators have been sufficient, and no more items could contribute to customer dissatisfaction.

Figure 1. Importance Performance Analysis (IPA) Matrix

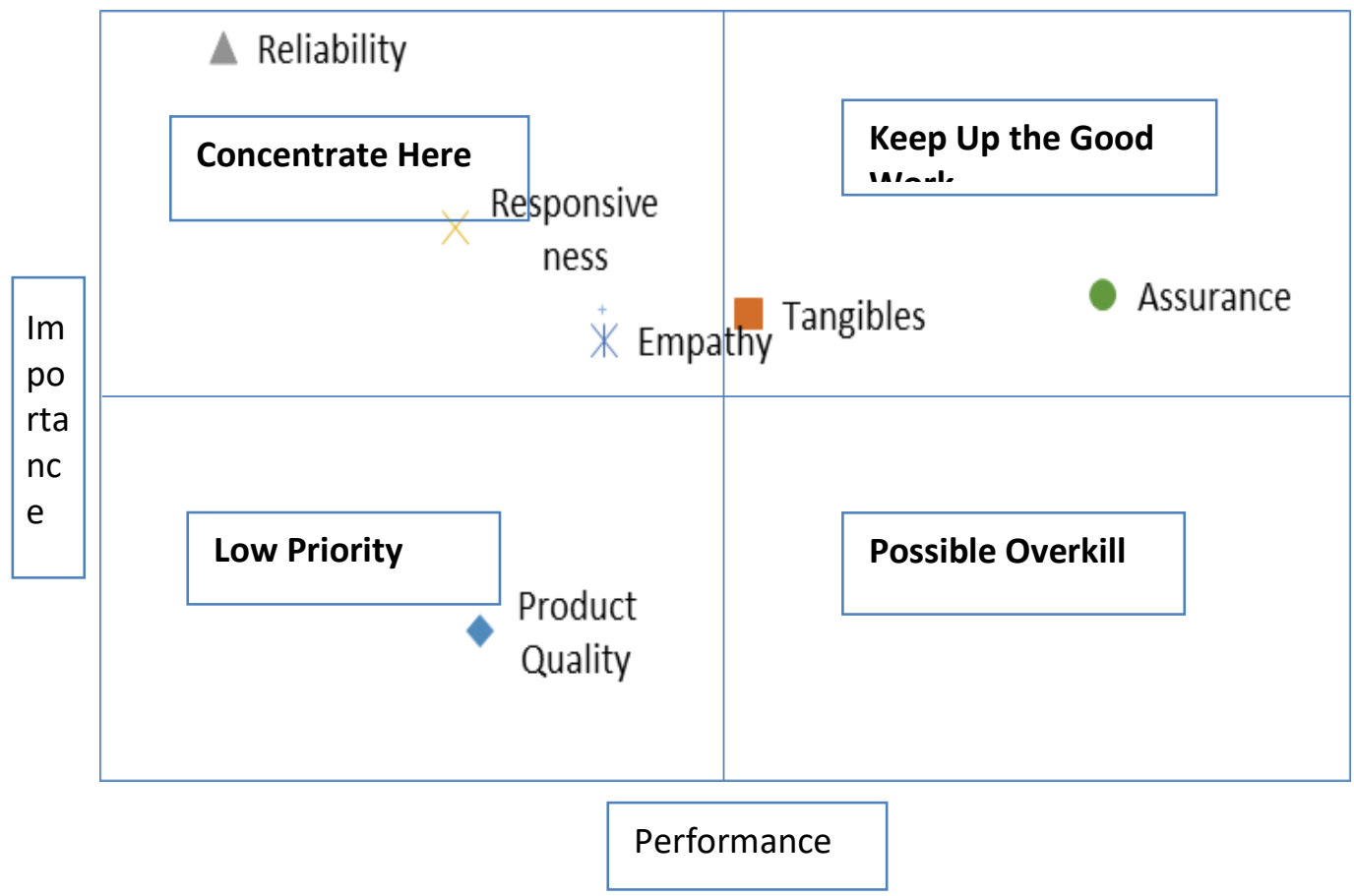

\subsubsection{Customer Satisfaction Index (CSI)}

The overall score of the CSI was 75.05 which means that the customers were satisfied and reflected the overall actual performance as perceived by them. The challenge has been to increase the CSI to a minimum score of 80.01 which would satisfy the customers even better. 


\section{Conclusion}

\subsection{Summary}

a) Overall, the performance of the operators is still below the expectations of the customers. Micro-environments were the most affected. Marketing communication has been limited and system operations were run manually. Marketing through social media was applied with limitation, and operations are not yet applied through IT and e-office advancement.

b) IPA results show there are big gaps for Responsiveness, Empathy and Tangible constructs. Thus, strategies directed towards increasing HR skills are needed. Nevertheless, loyalty scores revealed the loyal customers to refer others and felt the staff were friendly. CSI scored 75.05, which means customers are satisfied, but one still needs to increase the performance.

c) Other indirect competitors, including Grab and Uber, plus other non-online conventional taxis, as well as airport railway services which are to start soon, would increase the threat and market segment. The increasing number of the middle-income class has increased the ownership of cars, thus threatening the market share.

\subsection{Recommendations}

a) There is a need for socialization and the implementation of ServQual campaign, apart from increasing Product Quality features. The increase in staff skills, which should focus on personal and other soft skills, can be introduced. Furthermore, replacing old buses with new buses is imperative and this includes onboard facilities such as wifi and clean toilets. Quality Assurance, which would tightly control bus operations for each operator is needed for focusing towards better service establishment in the future, and with safety, timeliness, speedy and accuracy philosophies.

b) Key Success Factors (KSFs) for the operators would be: Differentiation strategies on systems, people, product and place; Focus on Operational excellence: safety, comfort, timeliness, effectiveness and cost-efficient; Integrated Marketing Communication (IMC); Enhance HR through education/training and skills for crews.

c) As far as the theoretical application for Juran's Quality focus goes, IPA and CSI have been two very important tools and can be widely used in other industries. Future research should focus on other aspects, such as pricing sensitivity, as there will be the introduction of the airport railway services this year. Secondly, research could focus on dynamic modelling of variant modes of transport, as well as the trending application of e-marketing for transport marketing. 


\section{References:}

Gaspersz, V. 2001. Total Quality management. Gramedia Pustaka Utama, Jakarta.

International Standard Organization: ISO 9000:2015. Quality Management Systems:

Fundamentals and Vocabulary.

Juran, J.M, 1998. Juran's Quality Handbook, $5^{\text {th }}$ ed. McGraw-Hill.

Kotler, P. and Keller, L.K. 2007. A Framework for Marketing Management, 3rd ed. New Jersey USA, Prentice Hall.

Martilla, J.A. and James, J.C. 1997. Importance-Performance Analysis. Journal of Marketing, 41(1), 77-79.

Parasuraman, A.V., Zeithaml, A. and Berry, L.L. 1995. A Conceptual Model of Service Quality and Its Implications for Future Research. Journal of Marketing, 39(1), 4150 .

Parasuraman, A., Zeithaml, V., Berry, L.L. 1991. SERVQUAL: A Multiple-Item Scale for Measuring Customer Perceptions of Service Quality. Marketing Science Institute, 64(1), 12-40. 